\title{
Colonial Wars, Colonial Alliances: The Alcora Exercise in the Context of Southern Africa
}

\author{
Maria Paula Meneses, Celso Braga Rosa, \\ Bruno Sena Martins
}

(Centre for Social Studies, University of Coimbra)

\begin{abstract}
Images of violence have marked the political landscape of southern Africa since the independence of Portuguese and British colonies. The recent discovery of secret documents attest to the alliance linking white supremacist governments in South Africa and Rhodesia with Portugal's corporatist-fascist regime. This article focuses on the roots of so much of this violence: the formation of a little-known but crucial white alliance in the subcontinent, code-named 'Exercise Alcora', which aimed to perpetuate the minority regimes in the region. South Africa, Rhodesia and Portugal, with its two colonies of Mozambique and Angola, thus constituted a political project that sought to frustrate African liberation movements. A critical approach to the (re) construction of national memories is then crucial to understanding the roots of present-day social and political crises in southern Africa, as well as to recognising how important Exercise Alcora, as revealed in confidential documentation, was for the maintenance of white hegemony in this region until the very end of the 20th century. While South African-Rhodesian relations have been extensively dealt with in the literature, the relations between those countries and Portugal were more tenuous and shadowy.
\end{abstract}

\section{Introduction: The Dawn of Alcora ${ }^{1}$}

The focus of this article is the analysis of some neglected political developments in southern Africa reflected in preserved historical sources - both written and oral - brought to life in recently declassified documents from Portuguese archives. These documents shed new light upon the political and military pacts among white minority regimes in southern Africa in their attempts to defy the winds of change of African nationalism after 1960. This article, it should be emphasised, focuses on Portuguese archives concerning Angolan and Mozambican contexts, given that English, North American and, to some extent, South African archives, which focus on the South Africa-Rhodesia axis - have been well explored in recent years. There is no intention here, therefore, to analyse in detail the Rhodesian and South African backgrounds. This article proposes, firstly, in the light of Portuguese archival sources, to analyse the political impact of Alcora; secondly, to use the alliance as a window to investigate and (re-)interpret the impact of these white-ruled states' political decisions, which were taken with the aim of defeating African liberation movements; and, finally, to demonstrate the extent to which Alcora was at the core of regional violence, which has affected the subcontinent until quite recently.

1 'Alcora' is an acronym for the Aliança Contra as Rebeliões em Africa, frequently referred to in documents as Operation Alcora or the Alcora Alliance. In this article, it is also referred to as Exercise Alcora, or simply Alcora. For recent discussions of Alcora, see F.R. Meneses and R. McNamara, 'The Last Throw of the Dice: Portugal, Rhodesia and South Africa, 1970-74', Portuguese Studies, 28, 2 (2012), pp. 201-15; F.R. Meneses and R. McNamara, 'The Origins of Exercise ALCORA, 1960-71', International History Review, 35, 5 (2013), pp. 1113-34. 
Indeed, many of the problems resulting from events often described as civil unrest - or civil wars - in southern Africa are reflections of political choices involving several political actors who are almost forgotten today. In an interview given in 2010 to Rádio Moçambique, Joaquim Chissano $^{2}$ stated, in relation to conflicts following independence, that

the real causes for the war of destabilisation that started in 1976 are the same ones that made Portuguese colonialism resist the independence of Mozambique.[...] The war of destabilisation in Mozambique resulted from the failure in the dialogue attempts between the liberation movements of neighbouring countries with the - by then - minority regimes of Ian Smith, in Southern Rhodesia, and of apartheid, in South Africa. ${ }^{3}$

Why was Alcora established? Who benefited from it? Documents recently uncovered add new data regarding southern Africa's recent past. Taking into account narratives about wars as active constructions of meaning, this research draws on contemporary documents, personal accounts, secondary works and recorded interviews.

\section{White Collaboration in Southern Africa}

The end of the Second World War was soon followed by the Cold War division of the world into two major blocs: the West, led by the USA and supported after 1949 by allies in NATO, and the East, led by the Soviet Union and supported after 1955 by its allies in the Warsaw Pact. Communism was by then seen by the USA as a real threat to the western way of life, a perception shared by the European colonial powers and South Africa. ${ }^{4}$ The three signatories of the Alcora alliance not only shared a common interest - to maintain southern Africa under white control - but also saw themselves as the defendants of the last frontier of western civilisation in a continent in grave danger of being conquered by international communism.

In the 1950s and 1960s, independence was granted to French, British and Belgian colonies in Africa. The white-ruled Federation of Rhodesia and Nyasaland also had at this time extensive interests in several countries of the region, especially in Katanga province of the former Belgian Congo. ${ }^{5}$ Afraid of losing the Federation's influence and economic interests in Katanga, Sir Roy Welensky, its prime minister (1956-63), pursued an alliance with Katanga's whites and Belgian mining interests following the withdrawal of Belgium from the Congo in 1960 . He also sought to cultivate the support of the UK and the USA by arguing that any form of white control in southern Africa would greatly assist the fight against African nationalism, which he asserted was Soviet-controlled. Britain, however, showed little enthusiasm for supporting a white-controlled region, thus prompting him to initiate an alternative defence strategy involving the Portuguese, NATO allies of the British. ${ }^{6}$ As Hughes points out, even before 1963 the

2 Mozambican politician. Joining Frelimo in 1963, he became prime minister of the transitional government of Mozambique in 1974. After independence, he became minister of foreign affairs and, after the death of Samora Machel in 1986, President of Mozambique until 2005.

3 J. Chissano, 'Há Gente Com Tendência Para Desprezar e Deturpar a História', Rádio Moçambique, 10 October 2010, available at http://macua.blogs.com/moambique_para_todos/2010/10/joaquim-chissano-h\%C3\%A1-gente-comtend\%C3\%AAncia-para-desprezar-e-deturpar-a-hist\%C3\%B3ria.html, retrieved 4 February 2014 (our translation from Portuguese).

4 See V. Shubin, The Hot Cold War: The USSR in Southern Africa (London, Pluto Press, 2008). Ritchie Ovendale, The English-Speaking Alliance: Britain, the United States, the Dominions, and the Cold War, 1945-1951 (London, Allen \& Unwin, 1985).

5 For further insights into the Congo and relations between Katanga and the Central African Federation, see M. Hughes, 'Fighting for White Rule in Africa: The Central African Federation, Katanga and the Congo Crisis, 1958-1965', International History Review, 25, 3 (2003), pp. 592-615; IAN/TT, 'Ligações aos serviços secretos da Federação das Rodésias, Niassalândia e África do Sul' (n.d.), Arquivo da PIDE, Serviços Centrais, Pasta 1, Processo 6341/A-CI(2).

6 See Hughes, 'Fighting for White Rule in Africa, pp. 597-8. L.J. Butler, 'Britain, the United States and the Demise of the Central African Federation, 1959-63', Journal of Imperial and Commonwealth History, 28, 3 (2000), pp.131-51. 
Rhodesian secret service was already forging links with both Portuguese Africa and South Africa, including extra-territorial Federation-Portuguese joint operations in places such as Dar es Salaam. ${ }^{7}$ White-ruled Rhodesia's Unilateral Declaration of Independence (UDI) from Britain in 1965 marked a reversal of this trend towards decolonisation, and this event would come to play a major role in the evolution of a white political project for southern Africa. Settlers' fears of an advancing African nationalism, supported by Soviet communism, combined with lack of support from Britain, were key factors in the election of a hard-line Rhodesian Front government in $1962 .{ }^{8}$ Rhodesian resolve to resist this perceived African nationalist-'communist' onslaught was strengthened in 1964 by the leadership of Prime Minster Ian Smith, whose UDI a year later can be seen as a key turning point for the white communities' control strategies for southern Africa. ${ }^{9}$

South Africa's 'official' collaboration with Portugal, supposedly against the threat of communist expansion, can be traced as far back as 1955, when an informal proposal was presented by the foreign minister of South Africa, Eric Louw, to the Portuguese ambassador regarding common interests in sub-Saharan Africa. ${ }^{10}$ This proposal envisaged a gathering of representatives from the governments of Belgium, France, Portugal, the United Kingdom and the Union of South Africa in order 'to exchange views and make proposals for future actions'.${ }^{11}$ For Portugal, such co-operation was perceived to be highly beneficial, although some reservations arose about an open collaboration with South Africa. The Portuguese authorities opted, first, for a careful analysis of its potential impacts through proper diplomatic channels. Only afterwards would an international conference be considered. ${ }^{12}$

Nevertheless, from as early as the late 1940s, the strategic presence of international capitalist interests and economic co-operation in southern Africa was becoming all too evident. In Mozambique, the USA had plans to make Nacala the harbour for its 7th Fleet, in order to patrol the maritime traffic in the Indian Ocean. Moreover, Gulf Oil ${ }^{13}$ had held the concession for natural gas and oil prospecting since 1948, and multinational corporations, such as Hurst International and Oppenheimer/Elf, were established in the territory. In Angola, in the 1960s,

7 See Hughes, 'Fighting for White Rule in Africa', p. 613. Further information confirmed these linkages, including the execution of several clandestine missions by Portuguese infiltrated agents, in Tanzania, up to the early 1970s. See Portuguese Historical-Diplomatic Archives - Arquivo Histórico-Diplomático (hereafter AHD), 'Relatório das Noticias Recolhidas de uma fonte de informação, por um dos adjuntos do SCCI, em Salisbury, de 21 a 24 de Setembro de 1964 - Secret', file 8774; 'Letter from Mozambique Governor to the Oversea Minister in Lisbon Secret', 19 February 1963, file 8776; Arquivo da Defesa Nacional - National Defense Archives (hereafter SGDN), 'Pedido de informações - secreto' - cx. 4249.4, vol. 1(c), 1 May 1965. The archival data was substantiated by information provided by a former Alcora operative, interviewed by the authors, Lisbon, June 2014.

8 D. Lowry, 'The Impact of Anti-Communism on White Rhodesian Political Culture, c.1920s-1980', in S. Onslow (ed.), Cold War in Southern Africa: White Power, Black Liberation (London, Routledge, 2009).

9 See L.F.M. Barroso, 'The Independence of Rhodesia in Salazar's Strategy for Southern Africa', African Historical Review, 46, 2 (2014), pp. 1-24.

10 See J. Daniel, 'Racism, the Cold War and South Africa's Regional Security Strategies, 1948-1990', in Onslow (ed.), Cold War in Southern Africa, pp .35-54; A.N. de Souto, 'Relações entre Portugal, África do Sul e Rodésia do Sul e o Exercício Alcora: Elementos Fundamentais na Estratégia de Condução da Guerra - 1960-1974', in M.P. Meneses and B.S. Martins (eds), As Guerras de Libertação e os Sonhos Coloniais: Alianças Secretas, Mapas Imaginados (Coimbra, Almedina, 2013), pp. 143-69; and A.N. de Souto, Caetano e o Ocaso do 'Império': Administração e Guerra Colonial em Moçambique durante o Marcelismo (1968-1974) (Porto, Afrontamento, 2007). For contemporary insights regarding the collaboration between Portugal, South Africa and Rhodesia, see R. Ainslie, The Unholy Alliance: Salazar-Verwoerd-Welensky (London, Anti-Apartheid Movement, 1962).

11 See AHD, 'União da África do Sul. Departamento de Negócios Externos. Aide Mémoire. Cape Town', 21 March 1955, pp. 1-2 (our translation from Portuguese).

12 AHD, 'Telegrama para Consulado de Portugal em Salisbury, de 1 de Julho de 1955, $\mathrm{n}^{\circ}$ geral 1873, n A-1, do Director-Geral dos Negócios Políticos do MNE', FNE-PAA, 368, 1 July 1955.

13 Founded at the beginning of the 20th century, Gulf Oil was one of the biggest North American oil companies until the 1980s. 
Gulf Oil initiated oil extraction in Cabinda, and the Compagnie française des pétroles (French Petroleum Company), Texaco and Petrangol ${ }^{14}$ were joined by the Anglo-American Corporation of South Africa, all of which were investing strongly in the Angolan oil sector. In addition, Krupp, the German steel and armaments manufacturer, invested in iron exploration in Cassinga.

A further element in economic co-operation and resource exploitation was initiated in 1964, when South Africa proposed the creation of a Southern African Common Market (SACOM), comprising South Africa, Rhodesia, Angola, Mozambique, Lesotho, Swaziland, Botswana and Malawi. Furthermore, an agreement was signed between Portugal and South Africa for the construction of the Cahora Bassa dam in Mozambique and the development of the Cunene valley hydro-electric project in Angola. ${ }^{15}$ These projects and financial endeavours clearly ensured that development strategies and regional integration would be based on a pre-existing colonial socio-economic structure in southern Africa that had to be protected at all costs.

With the outbreak of the nationalist armed struggles for independence in Portugal's African colonies in the early $1960 \mathrm{~s},{ }^{16}$ projects in which South African and international capital had invested in those colonies became increasingly at risk, and drastic measures had to be taken. ${ }^{17}$ To consolidate its vision for the region, South Africa, the region's political and economic leader, began strengthening relations with Ian Smith's Rhodesia and Salazar's ${ }^{18}$ Angola and Mozambique. Their secret services, South Africa's Bureau of State Security (BOSS), Portugal's Polícia Internacional e de Defesa do Estado (PIDE) and Rhodesia's Central Intelligence Organisation (CIO), ${ }^{19}$ initiated co-operation in the identification of 'problematic' political movements, and began arresting individuals who represented a threat to their political projects. Different possible scenarios had to be studied, but Portugal always insisted on discussing these measures in secrecy, so that co-operation could be officially denied if the country was to be questioned about it. Salazar's Portugal had no intention of becoming publicly associated with apartheid South Africa.

From the 1960s, South Africa attempted repeatedly to sign an agreement with Portugal that would include the possibility of intervening in Portuguese-ruled Angola and Mozambique. For South Africa, its future and that of Rhodesia were perceived to be inter-connected with the way Portugal would conduct and ultimately win the war against African nationalists in these territories. Telegrams exchanged between the Portuguese embassy in Pretoria and the Portuguese ministry of foreign affairs reveal the Portuguese conviction that South Africa and Rhodesia considered their territories in Africa as 'their own flanks', and that the South Africans and Rhodesians would intervene in those territories 'whether we want it or not, in case our own defence proves incapable of sustaining the attack' ${ }^{20}$ For Portugal, that was reason enough for an agreement to be urgently considered; otherwise it could mean that South African and Rhodesian operations could be conducted in Portuguese colonial territories without prior approval by Portuguese authorities. Later, in 1961, the South African foreign minister, Eric Louw, stated

14 Jointly owned by the Belgian group Petrofina S.A. and the local Portuguese colonial government.

15 Cahora Bassa, as an energy and defence project, was conceived to benefit not only Mozambique but also extensively South Africa; the Cunene valley project would serve Angola, but also the South African-controlled South-West Africa (present-day Namibia).

16 Initially, with the União dos Povos de Angola (UPA - Union of Angolan Peoples) in northern Angola in 1961, and Frelimo in Mozambique in 1964.

17 S. Onslow, 'The Cold War in Southern Africa: White Power, Black Nationalism and External Intervention', in Onslow (ed.), Cold War in Southern Africa, pp.9-34; G. Evans, 'The Cold War and South Africa, 1948-1994', in A. Dobson (ed.), Deconstructing and Reconstructing the Cold War (London, Ashgate, 1999).

18 António de Oliveira Salazar served as the head of Portugal's government 1932-1968, a period known as the 'Estado Novo', a dictatorship dominated by a right-wing corporatist policy.

19 For insights of a senior CIO officer, see K. Flower, Serving Secretly: An Intelligence Chief on Record Rhodesia into Zimbabwe, 1964 to 1981 (London, John Murray, 1987).

20 AHD, 'Telegramas da Embaixada de Portugal em Pretória', nº geral 4278, n 210, FNE-PAA 368 , 19 August, 1960; ${ }^{\circ}$ geral 4292, $n^{\circ} 211$, FNE-PAA 368, 20 August, 1960; $n^{\circ}$ geral 4298, nº 215, FNE-PAA 368', 21 August 1960 (our translation). 
publicly that in order to preserve 'western civilisation' in the 'dark continent', South Africa would have to co-operate with the Rhodesian and Portuguese authorities. ${ }^{21}$

Reports of a white alliance ${ }^{22}$ began reaching the wider public in the early1960s. In 1963, the Portuguese Governor of Angola drew Portugal's attention to the advantages of constituting a united front in both Angola and Mozambique alongside Rhodesia and South Africa. ${ }^{23}$ To the Portuguese, this was vital, due not least to the possibility of making use of more and better resources, including military vehicles, planes, ammunition and military technology, as well as the possibility of conducting joint actions with South African and Rhodesian troops, who would augment the meagre resources of the Portuguese army. In 1963, the Portuguese leader, Salazar, wrote to the South African prime minister, Hendrik Verwoerd, ${ }^{24}$ emphasising the role of Portugal in the defence of western civilisation in southern Africa, and underlining that every form of co-operation with Portugal would be extremely welcome. In 1965, Franco Nogueira, the Portuguese minister of foreign affairs, caught between supporting the Rhodesian UDI and affronting its old ally, the UK, decided in favour of tacit support and concluded that Portugal could expect nothing from the UK. Portuguese support for the Smith government in Rhodesia was pragmatic, stopping just short of full diplomatic recognition of the Smith government by accepting its diplomatic mission in Lisbon as a 'legation', but not as an 'embassy', aware that if Rhodesia survived, Portugal would gain 250,000 white settler allies in southern Africa. ${ }^{25}$ This reveals much about the strategies and interests of the Portuguese regime at the time, as it explored new alliances and disregarded older ones to defend the maintenance of its colonial territories in the continent. ${ }^{26}$ Two years later, in March 1967, a note from General Câmara Pina, the Portuguese army chief of staff, to the South African authorities, highlighted Portugal's urgent needs for the defence of its African territories, including military equipment, vehicles, ammunition, radio sets and medicines. ${ }^{27}$

By 1968, when Salazar was succeeded by Marcello Caetano, ${ }^{28}$ the more enlightened sectors of the Portuguese regime had already understood that the regime itself would be endangered, since its own survival was linked to the autonomy of the Portuguese colonies in Africa. ${ }^{29}$ Although Caetano, before taking office, had publicly favoured autonomy ${ }^{30}$ for the Portuguese 'African Overseas Provinces', ${ }^{31}$ documents concerning Alcora reveal that his political preference was precisely the opposite. He had already made up his mind, and his approach to African nationalism was clearly a military one. ${ }^{32}$ His position cannot be understood without an understanding of the support he had anticipated from his 'new' southern African allies. A dispatch from the Portuguese minister of defence, on 27 February 1969, thus clearly stated:

21 See Diário de Notícias, Lisbon, 25 February 1961.

22 See Diário de Notícias, 1 January 1962.

23 AHD, 'Telegramas s/n do Governador-geral de Angola de 22 de Maio de 1963. Secreto', PAA, 368, 22 May 1963.

24 Hendrik Verwoerd was South Africa's prime minister from 1958 until he was assassinated in 1966.

25 See F. Nogueira, Um Político Confessa-se (Diário: 1960-1968) (Porto, Civilização, 2000), pp. 141-2.

26 For an analysis of the relationship between Portugal and Zambia during this period, see L. Barroso, "“A Trick with Rebounds": Portugal, Zambia and the Rhodesian crisis (1967-1968)', Portuguese Journal of Social Science, 12, 2 (2013), pp. 195-209.

27 For further discussion, see A. Afonso and C.M. Gomes, Os Anos da Guerra Colonial: 1961-1975 (Matosinhos, Quidnovi, 2010).

28 Marcello Caetano became the last president of the Estado Novo, serving from 1968 until 1974, when the government was overthrown by the coup d'état of 25 April.

29 With the colonies functioning as a market for Portuguese goods and a source of raw material for Portuguese industries.

30 This idea was circulated before he replaced Salazar as head of the Portuguese government. After the Portuguese coup d'état, Marcello Caetano went into exile in Brazil, where he wrote about his political options and gave several interviews stating that his position was towards the progressive autonomy of the colonies. See M. Caetano, O 25 de Abril e o Ultramar: Três Entrevistas e Alguns Documentos (Lisboa and São Paulo, Editorial Verbo, n.d.), p. 25.

31 Political designation given by Portugal to its African colonies in order to make them fall outside the scope of UN resolutions and sanctions regarding colonies.

32 For further discussion, see Souto, Caetano e o Ocaso do Império. 
we find collaboration with Rhodesia indispensable to the defence apparatus for southern Africa, including, therefore, Portugal (Angola and Mozambique), South Africa and Rhodesia. It is too soon, nevertheless, to set alliances or military pacts in motion amongst these countries, so as not to arouse public opinion in those countries, though military agreements are growing tighter and in a better understanding. ${ }^{33}$

Portugal, struggling to present itself as a multi-racial nation, technically ruling 'overseas provinces' rather than colonies, ${ }^{34}$ had no wish to arouse adverse public opinion by joining a coalition with regimes identified as racist by the international community. Nevertheless, in its choice of allies, Portugal was effectively co-operating, even if with some reservations, with apartheid-ruled South Africa and white-minority-ruled Rhodesia.

Strongly worded UN resolutions and sanctions to end colonial rule had little practical effect in the region. The western powers, led by the USA, felt that they needed to keep southern Africa free of communist influence in the global struggle with the Soviet Union. ${ }^{35}$ A 1948 top secret document from the US State Department, even if referring to Asia rather than Africa, had already made it clear that questions of human rights, justice and economic and social progress were quite secondary in the Cold War:

We need not deceive ourselves that we can afford today the luxury of altruism and world benefaction.

[...] We should cease to talk about vague and [...] unreal objectives such as human rights, the raising of living standards, and democratization. The day is not far off when we are going to have to deal in straight power concepts. The less we are then hampered by idealistic slogans, the better. ${ }^{36}$

Southern Africa, with its natural resources and the strategic importance of the Cape sea route, was perceived to be much too important for the world economy, and the USA - as well as other western UN members, had an interest in keeping the region under western influence. ${ }^{37}$ Bearing this in mind, it can be argued that, in spite of the American anti-colonial public rhetoric, a white southern Africa was instrumental both to its economic interests and as a bulwark against the communist threat. ${ }^{38}$ Some authors give such importance to economic rationale that they even suggest that "it is perhaps more correct to view the Soviet "threat" as a clumsy pre-emptive act of US imperialism to justify its aggressive policies' ${ }^{39}$ Nevertheless, as the report on Africa commissioned by Henry Kissinger ${ }^{40}$ in 1976 argued, there was no hope that black Africans would gain political rights through violent means, and that western interests in Africa would necessarily have to be defended through alliances with the local white interests in the region.

33 AHD, 'Muito Secreto. Urgente. Assunto: Estudo de dispositivo para a defesa da África Austral', FSJB, SGDN, $n^{\circ}$ 513/RB, proc. 5975, Cx. 5696.21, to Director-General of Political Affairs of the Portuguese Foreign Office, 1 March, 1969 (our translation).

34 See M. Caetano, Somos Todos Portugueses Iguais à Face da Pátria e Iguais à Face da Lei (Lisboa, Secretaria de Estado da Informação e Turismo, 1969).

35 For further discussion of this point, see I. Mandaza, 'Southern Africa: US Policy and the Struggle for National Independence', African Journal of Political Economy, 1 (1986), pp. 120-41; Anna-Mart van Wyk, 'The USA and Apartheid South Africa's Nuclear Aspirations, 1948-1990', in Onslow (ed.), Cold War in Southern Africa, pp. 55-83; G. Horne, The US and the War Against Zimbabwe, 1968-80 (Harare, Sapes Books, 2001).

36 G. Kennan, 'Review of Current Trends: U.S. Foreign Policy (PPS/23)', in United States Department of State, Foreign Relations of the United States, 1948. General. The United Nations. Volume I, Part 2 (Washington, US Government Printing Office, 1948), pp. 510-29, available at http://digicoll.library.wisc.edu/cgi-bin/FRUS/FRUSidx?type=goto\&id=FRUS.FRUS1948v01p2\&isize=M\&submit=Go+to+page\&page=524, retrieved 27 August 2013.

37 For a discussion of how several US administrations have dealt with Portugal and the colonial question, see W.W. Schneidman, Engaging Africa: Washington and the Fall of Portugal's Colonial Empire (Lanham and Oxford, University Press of America, 2004); R.M. Irwin, 'Imagining Nation, State and Order in the Mid-Twentieth Century', Kronos, 37 (2011), pp. 12-22.

38 See M.P. Meneses, 'O Olho do Furacão? A África Austral no Contexto da Guerra Fria (Década de 70)', in Meneses and Martins (eds), As Guerras de Libertação, pp. 41-58. For a confrontation of Cuban and North American politics in Africa, see P. Gleijeses, Conflicting Missions: Havana, Washington, and Africa, 1959-1976 (Chapel Hill and London, University of North Carolina Press, 2002).

39 See Mandaza, 'Southern Africa: US Policy', p. 126.

40 Then US National Security Advisor, under President Nixon. 
Whites were in Africa to stay, and all solutions would have to pass through alliances with them in the region. ${ }^{41}$

For Kissinger, apartheid-ruled South Africa had become a powerful ally in the Cold War confrontation, given the need to sustain a stable pro-western bastion in southern Africa. But, on the other hand, the American position had led to a political and military strengthening of African nationalist resolve. In accordance with the terms of the alliance signed between Portugal, South Africa and Rhodesia, ${ }^{42}$ their common enemy was also singled out as being African nationalist movements. ${ }^{43}$ Therefore the US had come to be seen as a subtle accomplice in the white alliance's ambitions. ${ }^{44}$ In a chapter concerning the alliances in southern Africa, Meneses and Martins point out that:

[c]onfrontations of power in this region of the world found a parallel in the geopolitical setting being designed there. For many, the Cold War is perceived as a system for peace maintenance between two worldwide factions, guided by the United States and the Soviet Union. Seen from this perspective, the history produced reveals itself filled with silences, as happens in what concerns the Third World. [...] Well, the African settings were among the most devastated places by the violent conflicts of the last stage of the Cold War. In the southern African context, associated with the clash of ideologies [...], several imperial projects were, likewise, in confrontation. ${ }^{45}$

These western/white alliances were not without consequences. Other international connections and alliances were also being forged involving African liberation movements present in the region. The 1969 Lusaka Manifesto, for example, clearly stated that countries adjoining whiteruled states, as part of the obligations advanced by the Organisation of African Unity (OAU), 'would prefer to negotiate rather than destroy, to talk rather than kill' ${ }^{46}$ OAU members, led largely by nationalist leaders, supported the movements and organisations committed to nationalist struggles in southern Africa. By then, both armed struggle and negotiations appeared potential solutions to the struggles for an end to white minority rule. However, the conciliation being offered to South Africa by the OAU, in exchange for an acceptance of the one man, one vote principle, was declined and thus postponed in South Africa for another two decades. A contrary white political project was being forged for the region, and its consequent military component: Alcora. A radical new hope for white-ruled southern Africa was on the horizon.

\section{Building a Military Strategy to Serve a White Political Project}

Portugal and Rhodesia were already facing African nationalist insurgencies within their borders, with South African participation in Portuguese military actions in Angola since the 1960s. South Africa was, by then, the only country in such a position able to provide enough support to affect the course of the war. At the same time, it attempted to appeal to opinion in the so-called 'free world' in support of the construction of a pro-western, essentially whiteruled, bastion in southern Africa, thus frustrating communist inroads among African liberation

41 See M.A. El-Khawas and B. Cohen, National Security Study Memorandum 39: The Kissinger Study of Southern Africa (Westport, Lawrence Hill, 1976), p. 105; Meneses, 'O Olho do Furacão?', p. 51.

42 See Afonso and Gomes, Os Anos da Guerra Colonial; N. Guardiola, 'A Aliança Secreta do Apartheid, Rodésia e Portugal', África 21, 30 (2009), pp. 17-25.

43 See Historical Military Archive - Arquivo Histórico Militar (hereafter AHM), 'Plan for the Defence of Southern Africa', Fundo 7, B, Série 44, Cx. 370, Nr. 1, p. 3, March 1970.

44 For an analysis of documents concerning US policies towards South Africa from the beginning of the 1960s, see K. Mokoena (ed.), South Africa and the United States: The Declassified History (New York, The New Press, 1993).

45 M.P. Meneses and B.S. Martins, 'Introdução: O Exercício Alcora no Jogo das Alianças Secretas', in Meneses and Martins (eds), As Guerras de Libertação, pp. 16-17.

46 See N.M. Shamuyarira, 'The Lusaka Manifesto Strategy of OAU States and its Consequences for the Freedom Struggle in Southern Africa', Utafiti, 2, 2 (1977), pp. 247-66, available at http://archive.lib.msu.edu/DMC/ African\%20Journals/pdfs/Utafiti/vol2no2/aejp002002006.pdf, retrieved 20 August 2013. 


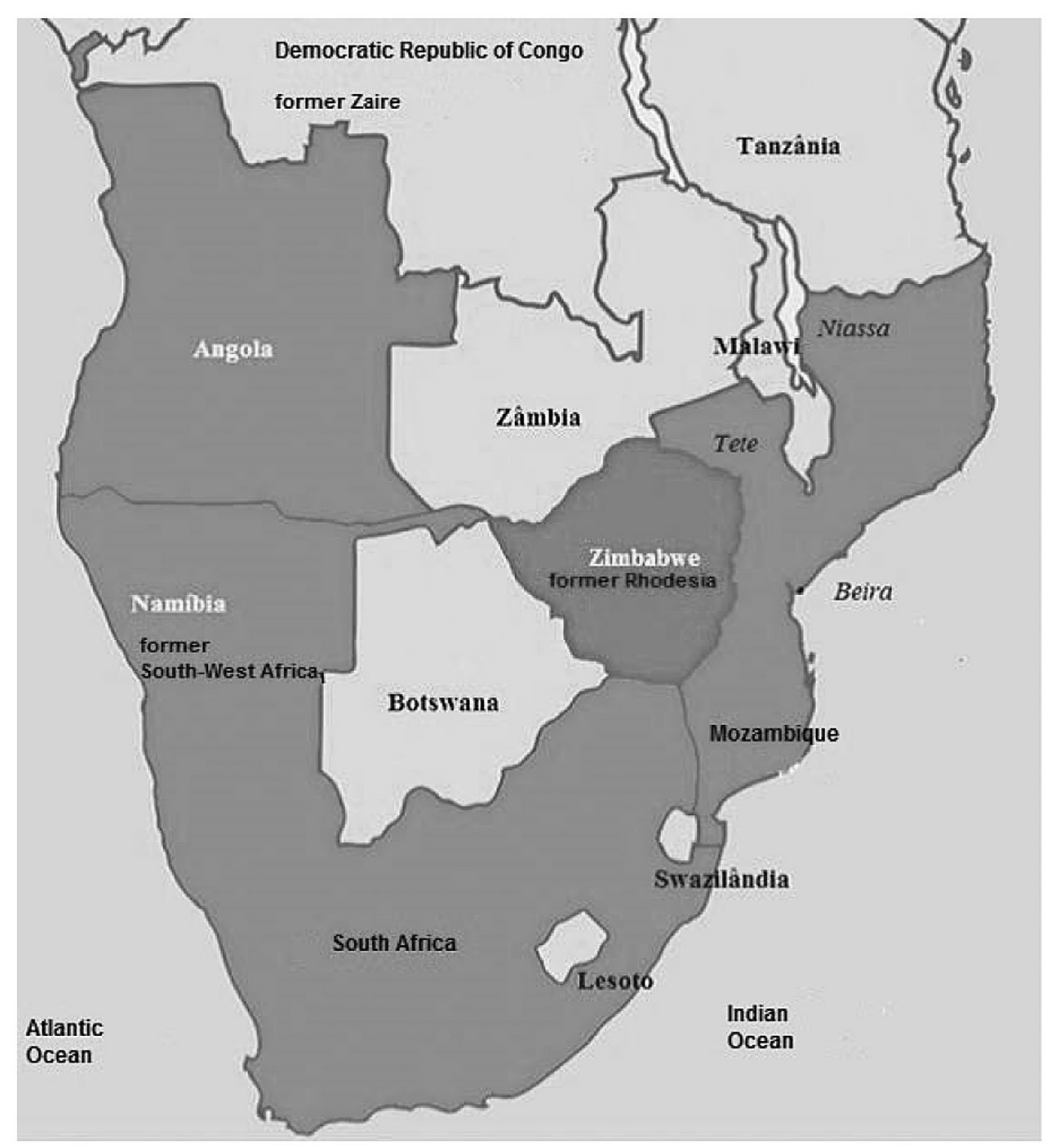

Figure 1. Configuration of white southern Africa in the early 1970s (Alcora territories).

movements ${ }^{47}$ This argument, given the Cold War scenario at that time, ${ }^{48}$ was expected to gain some support from the west, and the definition of a common enemy seeking to overthrow minority regimes was what characterised co-operation between Portugal, South Africa and Rhodesia. ${ }^{49}$

The maintenance of good relations between South Africa, Rhodesia and the Portuguese colonial administrations was, therefore, essential for the effectiveness of their counterinsurgency campaigns. As we have seen, since the mid 1960s these countries had been analysing the possibility of 'secret military pacts of mutual local assistance', ${ }^{50}$ and bilateral economic alliances. Portugal, however, was also a member of the North Atlantic Treaty Organisation

47 See Souto, Caetano e o Ocaso do 'Império'.

48 For a broader discussion of the Cold War in southern Africa, see R. Warwick, 'White South Africa and Defence, 1960-1968: Militarisation, Threat Perception and Counter Strategies', (DPhil thesis, University of Cape Town, 2009); V. Shubin, 'Unsung Heroes: The Soviet Military and the Liberation of Southern Africa', in Onslow (ed.), Cold War in Southern Africa, pp. 154-76; Shubin, The Hot Cold War.

49 See AHM, 'Plan for the Defence of Southern Africa', Fundo 7, B, Série 44, Cx. 370, Nr. 1, March 1970.

50 Arquivo Nacional da Torre do Tombo-Arquivo Oliveira Salazar (hereafter ANTT-AOS), 'Ensaio Sobre os Pontos Referidos no Discurso do Presidente do Conselho na Assembleia Nacional', Fundo AOS, CO, NE-30B, April 1962 (our translation). 
(NATO), and it attempted to link its struggles against African nationalists with its wider anticommunist obligations as part of that alliance. ${ }^{51}$

Since Ian Smith's UDI, Rhodesia had to deal with a growing number of commercial embargoes imposed by the UN. These sanctions left Rhodesia facing a shortage of oil, other basic products, and military equipment essential for security. ${ }^{52}$ In 1967, South Africa, realising the importance of helping a neighbouring white regime, established a security co-operation plan and sent military and police support to Rhodesia to assist in the counter-insurgency, and was keenly concerned that guerrilla incursions included fighters from the African National Congress of South Africa. ${ }^{53}$

Meanwhile, in Mozambique, guerrillas of the Frente de Libertação de Moçambique (Frelimo) nationalist movement began infiltrating Tete province from Tanzania, thus posing an acute threat south of the Zambezi river, including the provinces of Manica and Sofala, deep inside the territory. Rhodesia shared Portugal's concerns about these developments ${ }^{54}$ since this would allow joint actions between Frelimo and Zimbabwean nationalist forces. ${ }^{55}$ In reaction to this, Rhodesia reinforced participation of its own forces in the Portuguese war effort in Mozambique ${ }^{56}$ assistance which Portugal greatly appreciated:

what happened in Zumbo [Tete province, close to the Rhodesian border] is nothing but proof of our efforts to repay the precious services rendered to Portugal by the Rhodesian Armed Forces in Tete, done in such a spirit of decision, efficacy and loyal collaboration that we can't help feeling for Rhodesia anything but the greatest friendship. Our struggle is similar and we, the Portuguese, are also fighting to rescue western civilisation from the barbarians threatening to subvert the world. ${ }^{57}$

Rhodesia was aware that the independence of Mozambique from Portugal would signal the end of its access to the sea through the Mozambican port of Beira. Even more threatening was the likely establishment of bases and other infrastructures supporting Zimbabwean nationalist movements with the consent and protection of an independent Mozambican government. Furthermore, the political implications of a guerrilla victory in Mozambique were enormous, both internationally and in the encouragement that this would give to African nationalists within Rhodesia. In sum, the possibility of the independence of Mozambique would mean the beginning of the end for Rhodesia, and it was in this atmosphere that negotiations were held for the white secret military and economic alliance.

To South Africa, as the leading regional power, Alcora would be of the utmost importance in helping to fulfil its politico-economic aspirations, ${ }^{58}$ and it would allow South Africa to share responsibilities over the maintenance of their white project. As Davies argues, by means of a political alliance with other white regimes in the region, South Africa would be

51 Also in Guinea-Bissau, but this front falls beyond the scope of this article.

52 For an analysis of the position of Portugal towards the Rhodesian oil embargo, see C.R.W. Dietrich, "AA Climate of Collaboration": The Rhodesian Oil Embargo and Portuguese Diplomacy in Southern Africa, 1965-1967', Itinerario, 35, 1 (2011), pp. 97-120; C.R.W. Dietrich, “"The Sustenance of Salisbury” in the Era of Decolonization: The Portuguese Politics of Neutrality and the Rhodesian Oil Embargo, 1965-7', International History Review, 35, 2 (2013), pp. 235-55.

53 For a Rhodesian overview of the liberation war (also known as the 'Second Chimurenga', revolutionary war 1966-1979), see P.J.H. Petter-Bowyer, Winds of Destruction: The Autobiography of a Rhodesian Combat Pilot (Pinetown, $30^{\circ}$ South, 2005); J.R.T. Wood, So Far and No Further!: Rhodesia's Bid for Independence During the Retreat from Empire 1959-1965 (Bloomington, Trafford Publishing, 2012).

54 See I. Smith, The Great Betrayal: The Memoirs of Ian Douglas Smith (London, Blake Publishing, 1997), p. 159.

55 See J.P. Moiane, Memórias de um Guerrilheiro (Maputo, King Ngungunhane Institute, 2009).

56 See Afonso and Gomes, Os Anos da Guerra Colonial, p. 626.

57 AHM, 'Relações com a Rodésia: Patrulhamento a sul do r. Zambeze, na área a sul do Zumbo', Fundo 63, Série 31, Cx. 980, 23 February 1970 (our translation).

58 For an overview of the South African context, see D. Geldenhuys, The Diplomacy of Isolation: South African Foreign Policy Making (Basingstoke, Palgrave Macmillan, 1984). 
[a]ble to rely on the existence of a ring of colonially ruled 'buffer states' to ensure that the gathering liberation struggle in southern Africa remained largely confined to regions far distant from its own borders, and that regional territories continued to serve South African capitalism as labour reserves, markets, and suppliers of specific services such as transport. ${ }^{59}$

To the South African Defence Force (SADF), the strategy was to keep the defence line as far away as possible from South African borders. Thus Angola, Mozambique and Rhodesia would become the northern front lines of South Africa's strategy. In March 1970, South African and Portuguese military high representatives met to analyse the common situation in southern Africa. At this meeting, South Africa drew attention to the rapid deterioration of Portuguese military control in eastern Angola,${ }^{60}$ while emphasising that this crisis should not be seen as isolated from other insurgencies in Mozambique, Rhodesia, South-West Africa and Caprivi. The Portuguese highlighted the fact that the wars they were fighting in southern Africa represented a mobilisation greater than one per cent of the total metropolitan population, ${ }^{61}$ which was no easy task for a small, impoverished country. Portuguese and South African analyses revealed three fundamental concerns: the need for a permanent assessment of the threat evolution (information); the need for an assessment and co-ordination of human resources for the joint defence (general strategy); and the need for military forces' co-operation and joint use of infrastructures (military).

From the 1960s, the magnitude of the impact of decolonisation in the continent became increasingly significant, and South Africa was naturally very alert to these developments. It was felt that the time for radical action had arrived, due to an awareness of a developing pan-African nationalist alliance. As Lieutenant-General Fraser, commander-in-chief of the South African Joint Combat Forces, noted in a secret report from March 1970:

[i]n a conference conducted in Morogoro, Tanzania, between April 25th and May 1st 1969 by initiative of SAANC [ANC], the need was emphasized of strengthening the existing alliance between ZAPU (Rhodesia) and SAANC (RSA), through the inclusion of FRELIMO (Mozambique), of MPLA (Angola), ${ }^{62}$ of SWAPO ${ }^{63}$ (Southwest Africa and Caprivi) and of PAIGC (Portuguese Guinea) ${ }^{64}$ with the aim of gathering each one's resources and create a solid liberation front, in the fight against imperialist white domination in Southern Africa. ${ }^{65}$

Thus South Africa led the creation of a counter-revolutionary alliance. Alcora came to define unified strategies to confront a common enemy to South Africa and Rhodesia, which would support Portugal in the maintenance of military campaigns in the region. The fighting of three insurgencies ${ }^{66}$ in Africa was proving too much of an effort for an impoverished country such as Portugal, which, by the end of the 1960s, had, after Israel, the highest proportion in the world of people in arms. ${ }^{67}$ For Portugal, this alliance offered not only colonial survival but the endurance of its metropolitan regime.

59 R. Davies, 'The SADF's Covert War Against Mozambique', in J. Cock and L. Nathan (eds), War and Society: The Militarization of South Africa (Cape Town, David Philip, 1989), p. 107.

60 Precisely where South Africa was supporting Portuguese war efforts.

61 AHD, 'Plano de Defesa da África Austral (exposição portuguesa). Muito Secreto', FSJB, SGDN, Cx. 5568.2, March 1979.

62 Movimento Popular de Libertação de Angola - People's Movement for the Liberation of Angola

63 South West Africa People's Organisation.

64 Partido Africano da Independência da Guiné e Cabo Verde - African Party for the Independence of Guinea and Cape Verde.

65 AHM, 'Plan for the Defence of Southern Africa', Fundo 7, B, Série 44, Cx. 370, Nr. 1, p. 2, March 1970. See also C. Gurney, 'The 1970s: The Anti-Apartheid Movement's Difficult Decade', Journal of Southern African Studies, 35, 2 (2009), pp. 471-87.

66 Guinea-Bissau, Angola and Mozambique.

67 See J.P. Cann, Counterinsurgency in Africa: The Portuguese Way of War, 1961-1974 (London, Greenwood Press, 1997). 


\section{The Alcora Exercise}

Recently declassified archival material in Portugal provides new insights into how political and military co-operation between the three countries was strengthened, a process that reached its peak between 1970 and $1974 .{ }^{68}$ In 1968, a meeting of the command of special operations from the three countries took place in Pretoria. The goal was to co-ordinate the development of counterinsurgency operations in southern Africa ${ }^{69}$ In April that year, as a result of an informal agreement between the Portuguese and South African military, two joint air support centres were created in south-east Angola, one in Cuíto-Cuanavale, the other in Gago Coutinho. In 1969, another meeting took place in Lisbon, ${ }^{70}$ leading to the elaboration of a 'Plan for the Defence of Southern Africa' ${ }^{71}$ In these meetings, analyses were presented and important subjects were addressed, such as the impact of the menace, evaluation of tactics, combat execution regulations, intelligence, cartography, communications, equipment acquisition and psycho-social actions. On 14 October 1970, Alcora was signed by Portugal, South Africa and, shortly afterwards, Rhodesia. The organisational structure of the alliance ${ }^{72}$ defined in these meetings consisted of a tripartite Alcora Top Level Commission (ATLC), an Alcora Co-ordination Commission (ACC), and eight sub-commissions, which were designed to meet on a regular basis twice a year. In 1971, a third meeting took place in Salisbury (now Harare), Rhodesia, a major outcome of which was the establishment of a joint consultative commission on information and security, in order both to face the common challenges and to organise joint strategies and operations. At a national level, each commission and subcommission had their own representation to guarantee the co-ordination of all Alcora commissions; to guarantee the contacts between member countries, the Portuguese created the Comissão de Coordenação para os Assuntos do Ultramar (CCAU - Overseas Co-ordination Commission).

At the core of these meetings was a persistent discourse about the struggle 'against terrorism and communism', identified as the major threats in the southern Africa region. ${ }^{73}$ All Africans struggling for the independence of their countries from white rule became identified as terrorists supported by international communism. Thus, Alcora became essentially the military configuration of a South African political project ${ }^{74}$ for securing and maintaining a white-ruled pro-western southern Africa.

It was not always possible for the alliance to function on the basis of equality. Portugal frequently had to surrender co-ordination of operations within its own African colonies to its allies. Although all shared a common interest - to keep southern Africa safe and under whiteruled regimes - they also had their own objectives and frustrations. As pointed out by Portuguese officers who fought in African theatres of war, 'the strategic priority given by Marcello Caetano

68 In 1970, South Africa realised that nationalist movements were becoming stronger and better organised, jointly co-ordinating actions under the auspices of the OAU, with Russian inspiration, and alerted its allies in the region (Portugal and Rhodesia). See AHM, 'Plano de Defesa para a África Austral', Fundo 7, B, Série 44, Cx. 370, Nr. 1, March 1970.

69 IAN/TT, 'Comando das Operações Especiais', Arquivo da PIDE, Serviços Centrais, Processo 7477-CI (2).

70 D.C. Mateus, A PIDE/DGS na Guerra Colonial, 1961-1974 (Lisboa, Terramar, 2004), p. 358.

71 AHM, 'Muito Secreto. Assunto: Plano de Defesa para a África Austral. Inventário dos recursos estratégicos empenháveis na África Austral (considerando várias situações)', SGDN, $1^{\text {a }}$ Rep, Ref. Directiva SADN, FSJB, SGDN, Cx. 6179.1 (1 ${ }^{\circ}$ vol.), 4 June 1970; AHM, 'Muito Secreto. Assunto: Plano de Defesa para a África Austral. Inventário dos recursos militares empenháveis na África Austral (considerando várias situações)', SGDN, $1^{\text {a }}$ Rep, Ref. Directiva SADN, FSJB, SGDN, Cx. 6179.1 (1º vol.), 4 June 1970.

72 See Afonso and Gomes, Os Anos da Guerra Colonial; A. Afonso and C.M. Gomes, Alcora, O Acordo Secreto do Colonialismo: Portugal, África do Sul e Rodésia na Última Fase da Guerra Colonial (Lisboa, Divina Comédia Editores, 2013); A. Afonso, 'Exercício Alcora: Um projeto para a África Austral', in Meneses and Martins (eds), As Guerras de Libertação, pp. 109-22.

73 H. Ellert, The Rhodesian Front War: Counter-Insurgency and Guerrilla War in Rhodesia, 1962-1980 (Harare, Mambo Press, 1989), p. 5.

74 For an overview of the history of the South African political project, see M. Meredith, Diamonds, Gold and War: The Making of South Africa (New York, Pocket Books, 2008). 
to the alliance with Rhodesia and South Africa prevented any possibility of conducting the war in a different way from the one determined by its allies' ${ }^{75}$ Because of the complexity of the military situation and the interests involved, the alliance would always have primacy.

As a result of Alcora, Portugal also benefited from South African financial support. On 8 March 1974, a loan of R150 million was granted to Portugal by the South African Reserve Bank to enable Portuguese acquisition of military equipment that would better serve the country for its role within the alliance. ${ }^{76}$ But this support came too late. Within a month, on 25 April 1974, the alliance would come to an end, due to the military coup d'état in Portugal, which overthrew the dictatorship. This opened the way for the end of the wars in Angola and Mozambique. A last ATLC meeting took place in Pretoria on 24 June 1974. South African and Rhodesian authorities, still unaware of the full extent of the consequences of the coup d'état in Portugal, waited for that meeting with high expectations. ${ }^{77}$ Due to the political turmoil in Portugal, however, Portuguese military representatives attended the meeting only to put an end to the Portuguese presence in the tripartite alliance. Henceforth, all that remained of Alcora were the Rhodesian and South African strongholds and unofficial Portuguese movements still craving western support.

Thus, with the coup d'état in Portugal in 1974 and subsequent negotiations for a transition to independence, the white alliance suffered a final blow. The independence of Angola and Mozambique enabled the freedom fighters from Rhodesia - the Zimbabwe African National Union (ZANU) and the Zimbabwe African People's Union (ZAPU) - and those of SWAPO and the ANC to find other places to seek the shelter and support that allowed them to reorganise and challenge white minority-rule in Rhodesia and South Africa. ${ }^{78}$ From the late 1960s, ZAPU guerrillas co-operated closely with guerrillas from the ANC's armed wing, Umkhonto we Sizwe (MK), in Rhodesia, ${ }^{79}$ but it was after 1974 - in the post-détente era - that ZAPU would concentrate on guerrilla training, most of which took place in Tanzania, Zambia and Angola. ${ }^{80}$

Strong bonds continued to be forged between freedom fighters from several territories, but this did not immediately halt Rhodesian and South African ambitions to secure their positions. Their aggression continued to be directed against Angola, invaded by South African troops in August 1975, which led the MPLA to ask for aid from Cuban forces. ${ }^{81}$ Mozambique had to deal with major Rhodesian operations inside its territory in 1976, supported by the Rhodesianand South African-funded Resistência Nacional Moçambicano (Renamo), ${ }^{82}$ as well as other front line states. ${ }^{83}$

75 Afonso and Gomes, Os Anos da Guerra Colonial, p. 742 (our translation).

76 Ibid., p. 781.

77 For further discussions of the South Africa's diplomatic and strategic options after the Portuguese revolution, see F.R. Meneses and R. McNamara, 'South Africa and the Aftermath of Portugal's " Exemplary" Decolonization: The Security Dimension', Portuguese Studies, 29, 2 (2013), pp. 227-50; J. Miller, 'Things Fall Apart: South Africa and the Collapse of the Portuguese Empire, 1973-74', Cold War History, 12, 2 (2012), pp. 183-204.

78 See B.L. Machava, 'The State Discourse on Internal Security and the Politics of Punishment in Post-Independence Mozambique (1975-1983)', Journal of Southern African Studies, 37, 3 (2011), pp. 597-8.

79 Ellert, The Rhodesian Front War, p. 13.

80 Ibid., p. 11.

81 See D. O'Meara, Forty Lost Years: The Apartheid State and the Politics of the National Party (Johannesburg, Ravan Press, 1996), p. 222; Machava, 'The State Discourse on Internal Security', p. 598. For further readings, see D. Wheeler and R. Pélissier, História de Angola (Lisboa, Tinta da China, 2011); H. Helmoed-Romer, War in Angola: The Final South African Phase (Rivonia, Ashanti Publishing, 1990).

82 Mozambican National Resistance. See S.W. Cline, RENAMO, Anti-Communist Insurgents in Mozambique: The Fight Goes On (Washington, US Global Strategy Council, 1989); S. Malley, 'La Mort de Samora Machel: Pourquoi Ce Crime de Pretoria?', Afrique-Asie, 386 (1986), pp. 6-11.

83 The front line states (FLS) established an alliance to achieve democratic majority rule in southern Africa. Its members included Angola, Botswana, Lesotho, Mozambique, Tanzania, Zambia, Zimbabwe (from 1980). This alliance came to an end with the establishment of a majority democratic regime in South Africa. 
The former Portuguese colonies thus emerged into independence in a very politically hostile regional context. Although pressure from South Africa on its neighbouring states to align with its regime had a long history ${ }^{84}$ Alcora initiated an acute escalation of this strategy, and this violent colonial encounter remains to be addressed in all its complexity.

\section{Implications: Debris of Conflicting Political Projects}

Alcora proved that two competing and mutually antagonistic political projects and alliances were in confrontation in southern Africa during the Cold War. ${ }^{85}$ The information concerning Alcora offers new insights into southern Africa's colonial wars and their legacies. ${ }^{86}$ Many of the troops involved in those wars, struggling either for national liberation or for white rule, would later be involved in other regional conflicts. ${ }^{87}$ The principle behind Alcora - a concerted strategy to defend southern Africa from black nationalists - endured even after Portugal had lost its African colonies. Post-independence Angola and Mozambique inherited highly militarised populations owing to the Africanisation of war, as well as various factions dissatisfied with the way in which independence occurred, situations that South Africa and Rhodesia were able to exploit. Their intention was still to undermine the capacities of independence movements that came to power - Frelimo in Mozambique and the MPLA in Angola - and to ensure that these movements were unable to support nationalist movements within their own borders. Thus the counter-revolutionary mentality initiated by Alcora endured beyond the end of Portuguese colonial rule, and this is essential to understanding the 'post-colonial violent order' in the region. ${ }^{88}$ Moreover, the Africanisation of the Portuguese colonial army until 1974 is also a key element for a proper understanding of post-independence violence, as Coelho underlines:

[w] hatever the approaches and their degree of success in terms of furthering colonial interests, the fact is that on the eve of the war's end Africanisation had been accepted as the only way of maintaining the colonial project, in circles as high as that of the Portuguese Chief-of-Staff. According to him, African troops were more efficient, more cost-effective, cheaper and susceptible of delivering better results not only in military terms, but also politically. Moreover, if properly organised in militarised villages they could fight forever. In 1974 he therefore proposed a substantial reduction in the number of metropolitan troops and a decentralisation of the financial resources thus spared, so that the local commands could create further African units. Clearly, the plan was to promote preconditions for civil war in the African territories, if not politically, at least militarily. ${ }^{89}$

In the aftermath of the independence of Angola and Mozambique in 1975, thousands of highly trained African special troops that had been part of the Portuguese army were left behind in independent countries, and began to be seen with suspicion by the new political forces. In Coelho's opinion,

84 In the case of Mozambique, since the 19th century. See Covane, As Relações Económicas entre Moçambique e a África do Sul 1850-1964 (Maputo, Arquivo Histórico de Moçambique, 1989).

85 For the subject of southern Africa and the Cold War, see Onslow, Cold War in Southern Africa, and Shubin, The Hot Cold War.

86 For further discussions, see S. Onslow and A-M. van Wyk, Southern Africa in the Cold War, Post-1974 (Washington, Woodrow Wilson International Center for Scholars, 2013), available at https://www.wilsoncenter.org/sites/default/ files/CWIHP_SouthAfrica_Final_Web.pdf, retrieved 4 December 2013.

87 For Katanga mercenaries taking refuge in Angola, see Hughes, 'Fighting for White Rule in Africa', p. 612.

88 J.P.B. Coelho, 'Da Violência Colonial Ordenada à Ordem Pós-Colonial Violenta: Sobre um Legado das Guerras Coloniais nas Ex-Colónias Portuguesas', Lusotopie (2003), pp. 175-93, available at http://lusotopie. sciencespobordeaux.fr/borges2003.pdf, retrieved 20 August 2013.

89 J.P.B. Coelho, 'African Troops in the Portuguese Colonial Army, 1961-1974: Angola, Guinea-Bissau and Mozambique', Portuguese Studies Review, 10, 1 (2002), p. 147, available at http://www.ces.uc.pt/estilhacos_ do_imperio/comprometidos/media/African\%20Troops\%20in\%20the\%20Portuguese $\% 20$ Colonial\%20Army.pdf, retrieved 24 January 2017. 
[t]he heritage of heavily armed, disciplined and militarised contingents of African troops left behind by the hasty Portuguese decolonisation process, together with varying but generally narrow integration conditions offered by the new independent regimes, are the two factors that undoubtedly created a bridge between the colonial wars and the civil ones after the independence, particularly in Angola and Mozambique. ${ }^{90}$

The militarisation that these societies underwent during colonial campaigns bequeathed a legacy of violence beyond independence, which South Africa and Rhodesia continued to exploit. Another legacy of Alcora was their continuing ability to manipulate internal conflicts within liberation movements. Thus some African nationalists defected from their movements to create other liberation and political movements, often with local white or western support. In Angola, for example, Jonas Savimbi, leader of the União Nacional para a Independência Total de Angola (UNITA), ${ }^{91}$ initially accepted support from the Portuguese colonial authorities and later from apartheid South Africa in his fight against the MPLA government. Thus were sown the seeds for postcolonial internal conflict. In a modern version of 'divide and rule', the minds originally behind the project of a white-ruled southern Africa provided several African leaders, even before their countries became independent, with the weapons they could later use to maintain a cycle of violence for many years to come. ${ }^{92}$

\section{Acknowledgements}

We are grateful to the Foundation for Science and Technology, Portugal, for the grants that made possible this research: fcomp-01-0124-feder-009271; fcomp-01-0124-feder-019531; and fcomp-01-0124-feder-008664. We would like to express our gratitude to the insightful comments and suggestions of Aniceto Afonso, Amélia Souto, Catarina Gomes, Iolanda Vasile and Natércia Coimbra. We are also grateful to the personnel of the archives consulted.

Maria Paula Meneses

E-mail: menesesp@ces.uc.pt

Celso Braga Rosa

E-mail: celsobragarosa@gmail.com

Bruno Sena Martins

E-mail: bsenamartins@ces.uc.pt

Centre for Social Studies, University of Coimbra, Colégio de S. Jerónimo, Apartado 3087, 3000-995 Coimbra, Portugal. 